\title{
POPULATION DENSITY OF Elaeidobius kamerunicus FAUST IN DIFFERENT SPIKELET POSITION AT ANTHESISING MALE INFLORESCENCE OF Elaeis guineensis Jacq. IN SABAH AND SARAWAK, MALAYSIA
}

\section{SAHARUL ABILLAH MOHAMAD*,**; MUHAMMAD NURUL YAQIN SYARIF*; SITI NURULHIDAYAH AHMAD*; MOHAMED MAZMIRA MOHD MASRI*; KING JIE HUNG** and NORMAN KAMARUDIN*}

\begin{abstract}
The oil palm male inflorescences provide food source and breeding sites for the pollinating weevil, Elaeidobius kamerunicus (E. kamerunicus). The present study examined the difference in the formation of the oil palm male inflorescences on different soil types, and how the differences affect the population density of E. kamerunicus. Samplings of adult E. kamerunicus and the spikelets of fully-anthesising oil palm male inflorescences were conducted monthly for a period of 18 months at four oil palm plantations on peat and mineral soils in East Malaysia. Elaeidobius kamerunicus population density in peat soil areas was found to be lower than those in mineral soils $(P<0.05)$. It was also found that the male inflorescences spikelet length in the study sites on peat soil areas were less uniform; spikelets on the upper part of the inflorescence were significantly shorter $(=12.80 \mathrm{~cm})$ compared to the spikelets sampled from the bottom part of the inflorescence ( $=14.91 \mathrm{~cm}, P<0.05, P=0.000-0.031$ ). In addition, compared to the lower part of the inflorescence, significantly fewer weevils were found lodged on the spikelets sampled from the upper part of the inflorescence (Site $1^{\text {Top }}=8$ adult weevils per spikelet; Site $2^{\text {Top }}=12$ adult weevils per spikelet; Site $1^{\text {Bottom }}=18$ adult weevils per spikelet; Site $2^{\text {Bottom }}=17$ adult weevils per spikelet). However, no significant correlation was found between the length of the spikelet and the weevil density on each spikelet ( $r=0.021$ 0.181). The result from this study demonstrates the influence of the soil types on the formation of the inflorescence, which requires further investigation.
\end{abstract}

Keywords: Elaeis guineensis, Elaeidobius kamerunicus, different soil types, male inflorescence.

Received: 14 February 2020; Accepted: 12 June 2020; Published online: 8 October 2020.

\section{INTRODUCTION}

Oil palm (Elaeis guineensis) produces separate male and female flowers on the same plant in an alternating cycle, which is governed by varieties of factors, e.g. genetic, age and environmental

* Malaysian Palm Oil Board,

6 Persiaran Institusi, Bandar Baru Bangi,

43000 Kajang, Selangor, Malaysia.

E-mail: saharul.abillah@mpob.gov.my

** Institut Ekosains Borneo,

Universiti Putra Malaysia Bintulu Sarawak,

Jalan Nyabau, 97008 Bintulu,

Sarawak, Malaysia. conditions (Corley, 1976). The male inflorescence consists of a $40 \mathrm{~cm}$ stout peduncle bearing around 100-300 spikelets, which individually measures 10 $30 \mathrm{~cm}$ long. Each of the spikelets usually holds 4001500 male flowers. The female inflorescence has a shorter and stouter stalk, which holds 150 spikelets that contain 30 flowers each (Janick and Paull, 2008).

The oil palm pollinating weevil, Elaeidobius kamerunicus feeds on pollens and the soft part of male flowers, which is also the location for egglaying (Corley and Tinker, 2015). Both male and female inflorescences emit characteristic aniseed smell to attract adult E. kamerunicus and permit 
pollen transfers from male to female inflorescences (Muhamad Fahmi et al., 2016; Janick and Paull, 2008; Aisagbonhi et al., 2004; Hussein et al., 1991). However, due to lesser incentives offered (i.e. breeding sites, food), the number of weevils visiting the female inflorescences is lesser than the number of weevils visiting the male inflorescences (Chiu, 1984; Syed, 1980).

Sufficient pollination is important in the process of oil palm fruit development and yield production. Incomplete pollination can cause bunch failure, low bunch production, and low fruit set (Kamaruddin et al, 2018; Haniff and Roslan, 2002). Due to the ineffectiveness of locally-available oil palm pollinators, E. kamerunicus was introduced to Malaysia from Cameroon in 1981 to improve fruit set formation (Syed et al., 1982).

Subsequently, monitoring of the population establishment of the introduced pollinator was conducted to determine its population level in the oil palm ecosystem (Nurul Fatihah et al., 2018; Rahardjo et al., 2018; Syarifah Nadiah and Idris, 2016; Basri et al., 1987). The monitoring of the pollinator has to be done regularly to ensure its sustainability as well as to monitor changes that might positively or negatively affect the species. Ming and Bong (2017) and Chiu et al. (1984) reported that sampling of the spikelets of the anthesising male inflorescences as more reliable and able to give a better estimation to the pollinating weevil densities of the area. In order to get an estimation of E. kamerunicus population per unit area, adults E. kamerunicus should be sampled from anthesising male inflorescences, indicated by florets opening. Three spikelets should be sampled from each region of the inflorescence, namely top, middle and bottom parts to get a more reliable estimate (Nurul Fatihah et al., 2018; Basri et al., 1987).

The population of E. kamerunicus is affected by the sex ratio of oil palm inflorescence. The development of high yielding planting materials produced a greater number of female inflorescences and a lower number of male inflorescences (Prasetyo et al., 2014). In addition, environmental stimuli also influence the sex ratio of the inflorescence (Corley and Tinker, 2015). Elaeidobius kamerunicus depends on male inflorescences for its food source and breeding sites, so the scarcity of male inflorescences in a particular area may negatively affect the population levels of E. kamerunicus, which will also influence the pollination of oil palm. The plant growth is influenced by the soil type on which the palm is grown (Yahya et al., 2012; Chan et al., 2005; Hamza and Anderson, 2005). Additionally, the amount and composition of volatile organic compounds emitted by the inflorescences are also influenced by the soil type (Muhamad Fahmi et al., 2016). It is acknowledged that E. kamerunicus spends most of its entire lifetime on the male inflorescence (Ming and Bong, 2017; Chiu, 1984; Syed, 1980). However, to date, no detailed observation on the effects of the male inflorescence morphology on the population levels of the pollinating weevil was conducted. The influence of the soil types on the male inflorescence morphological development was also not studied previously.

Therefore, this study was conducted to investigate the population density of E. kamerunicus lodged at each region of the male inflorescences. This information can be used to assess the differences between the formations of male inflorescences, in terms of uniformity of spikelet length, in different areas of sampling. In addition, this study was also conducted to compare the population level of E. kamerunicus on different types of soil.

\section{MATERIALS AND METHODS}

\section{Location of the Study}

The study was conducted in four localities of oil palm plantations with commercial DxP planting materials, with three sites located in Sarawak and one site is in Sabah. Site 1 was a 5-year old oil palm (planted in 2010) planting on undulating compacted peat area in the Roban region, Sarawak (N1 ${ }^{\circ} 53^{\prime} 58^{\prime \prime}$ E111 $\left.{ }^{\circ} 12^{\prime} 19^{\prime \prime}\right)$. Site 2 was a 4-year old planting (planted in 2011) on peat in Pusa region, Sarawak $\left(\mathrm{N} 1^{\circ} 40^{\prime} 15^{\prime \prime} \mathrm{E} 111^{\circ} 13^{\prime} 13^{\prime \prime}\right)$, Site 3 was a 3-year old oil palm area (planted in 2012) on mineral soil in the Segangan area, Sabah (N5 $06^{\prime} 26.0^{\prime \prime}$ E118 $\left.26^{\prime} 50.3^{\prime \prime}\right)$ and Site 4 was a 5 -year old planting on mineral soil in Miri, Sarawak (N4 ${ }^{\circ} 7^{\prime} 52^{\prime \prime}$ E113 $\left.58^{\prime} 28^{\prime \prime}\right)$.

\section{Samples Collection}

The samplings of male inflorescences and adults E. kamerunicus at the experimental sites were conducted monthly from January 2015 until June 2016. At each site, an area of 10 ha was selected for the study. A total of 150 healthy, bunch-producing palms were then systematically selected, by marking every tenth palm within the study area. The samples of spikelets from male inflorescences were then collected at random from the marked-palms. At Site 1, Site 2, and Site 4, three spikelets each from the top, middle, and bottom portion (Figure 1) of 10 fully anthesising male inflorescences were sampled each month, giving a total of 90 spikelets monthly. At Site 3, due to lack of fully anthesising male inflorescences during sampling, three spikelets each from the top, middle, and bottom portion of four fully anthesising male inflorescences were sampled, giving a total of 36 spikelets monthly. The anthesis of male inflorescence starts with the opening of florets at the base which then opens gradually upwards in about three days (Syed, 1980). Fully anthesising spikelet is usually obtained on the third day of 
anthesis, when all florets opening up from the distal to the apical part of the floret, bearing the highest amount of pollen and emitting the highest amount of weevil-attracting volatile organic compounds.

The spikelets were carefully cut from each region of the inflorescences and stored in individual plastic bags. Samples were then brought to the laboratory for further processing. The total number of adult E. kamerunicus was then summed up and categorised according to the positions of the spikelets on the inflorescences. The length of each spikelet was also measured and compared.

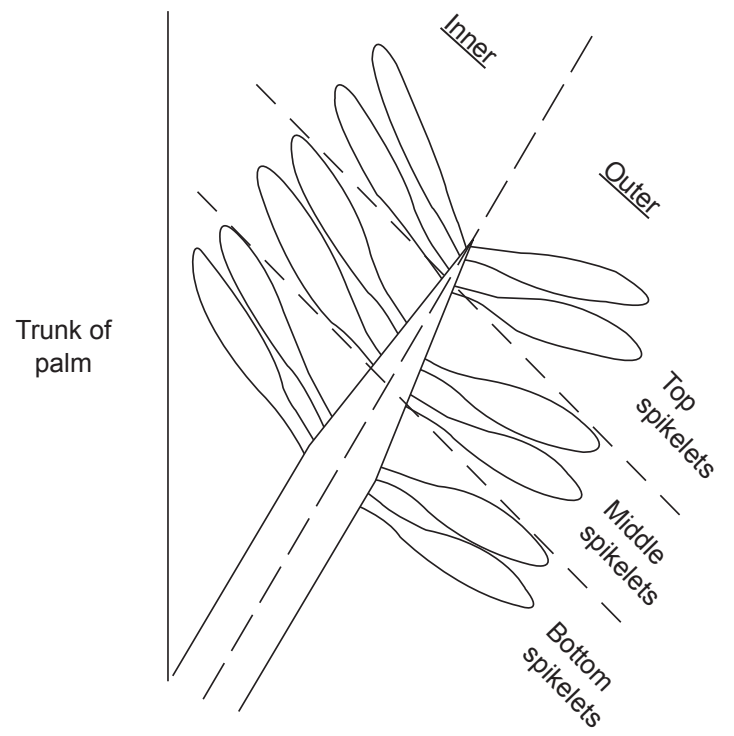

Figure 1. The six sections of the male inflorescence used in stratified sampling suggested by Chiu et al. (1984).

\section{Statistical Analysis}

All measured parameters were subjected to analysis of variance by using Minitab 17 software. Where applicable, means are then separated using Tukey's procedure $(\mathrm{P}<0.05)$.

\section{RESULTS}

\section{Population Density of E. kamerunicus in Different Soil Types}

A comparison between the number of adults E. kamerunicus lodged at the spikelets of the male inflorescences was conducted (Table 1). Based on statistical analysis, except for a few months (i.e. May 2015, July-October 2015), it was observed that the mean population density of E. kamerunicus per spikelet in mineral areas was significantly greater than that in peat areas $(\mathrm{P}<0.05, \mathrm{P}=0.000)$.

In addition, a comparison between each study site was also made and illustrated in Figure 2. The number of adult weevils per spikelet at both mineral soils at Site 3 and Site 4 were greater than those at peat soils (Site 1 and Site 2). The number of adult weevils per spikelet at Site $3(=31.51$ weevils per spikelet) was significantly greater than the number of weevils at Site 4 (= 25.98 weevils per spikelet), Site 1 ( = 21.20 weevils per spikelet $)$ and Site 2 ( $=15.11$ weevils per spikelet) $(\mathrm{P}<0.05, \mathrm{P}=0.000$ ).

Mean No. of adult weevils according to study sites

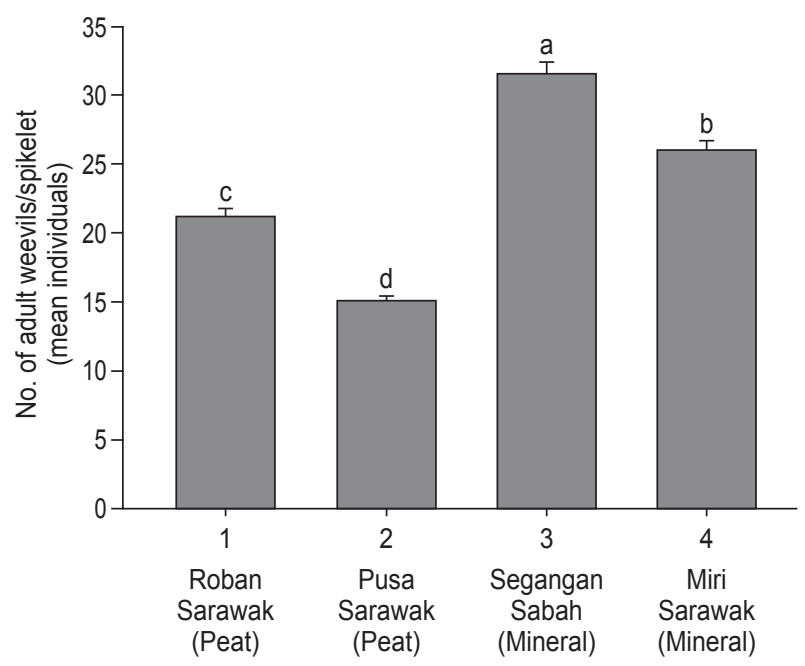

Figure 2: The mean number of adult weevils per spikelet in fully anthesising male inflorescences at the study locations (means that do not share a letter are significantly different).

\section{Male Inflorescence Spikelet Lengths from Different Portion of Inflorescence}

The length of spikelets from different parts of the male inflorescences from samples collected in the peat soil areas in Site 1, Sarawak, and Site 2, Sarawak were significantly different $(\mathrm{P}<0.05, \mathrm{P}=0.000-0.021)$ during the period of the study (Table 2, Figures 3 and 4). Meanwhile, in mineral soil areas in Site 3, Sabah, only samples collected in May 2015, June 2015, October 2015, January 2016 and March 2016 showed significant differences $(\mathrm{P}<0.05 \mathrm{P}=0.000-0.031)$ in terms of the length of the spikelets (Table 2). No significant differences in the length of the spikelets from different positions of male inflorescences were observed from the samples collected in another mineral soil site at Site 4 , Sarawak $(\mathrm{P}>0.05, \mathrm{P}=0.406$ 0.979) (Table 2).

From samples collected at Site 1 and Site 2, it was observed that the length of spikelets sampled from the top part of the inflorescences was generally shorter $\left(\right.$ Site $1^{\text {Top }}=11.91 \mathrm{~cm}$; Site $2^{\text {Top }}=12.55 \mathrm{~cm}$ ) compared to samples collected from other parts of the inflorescences (Tables 3 and 4). On the other hand, the length of the spikelets from the bottom part $\left(\right.$ Site $1^{\text {Bottom }}=14.68 \mathrm{~cm}$; Site $2^{\text {Bottom }}=15.13 \mathrm{~cm}$ ) was significantly longer than the spikelets collected from the top part, although the length of spikelets from those two parts with the spikelets from 
the middle part was not significantly different $\left(\right.$ Site $1^{\text {Middle }}=14.04 \mathrm{~cm}$; Site $\left.2^{\text {Middle }}=14.93 \mathrm{~cm}\right)$ $(\mathrm{P}>0.05)$.

Meanwhile, at Site 3, samplings conducted in May 2015, June 2015, September 2015, October 2015, January 2016, March 2016, May 2016, and June 2016 showed that the length of spikelets from the bottom part of the inflorescences (Site $3^{\text {Bottom }}=14.79 \mathrm{~cm}$ ) was significantly longer than those from the top part $\left(\right.$ Site $\left.3^{\text {Top }}=12.97 \mathrm{~cm}\right)($ Table 5$)$. Whereas, in other months of samplings, no significant differences were found between the length of spikelets from different portions of male inflorescence $(\mathrm{P}>0.05, \mathrm{P}=0.088$ 0.657) (Table 2, Figure 5).

Samples collected from Site 4 showed no significant differences in terms of the length of spikelets from a different portion of the male inflorescences $\quad(\mathrm{P}>0.05, \quad \mathrm{P}=0.406-0.979) \quad\left(\right.$ Site $4^{\text {Top }}$ $=14.07 \mathrm{~cm}$; Site $4^{\text {Middle }}=14.16 \mathrm{~cm}$; Site $\left.4^{\text {Bottom }}=14.18 \mathrm{~cm}\right)$ (Tables 2 and 6, Figure 6).

\section{Number of Adult Weevils in Spikelets of Male Inflorescences}

Generally, there was a significant difference between the number of adult weevils found in all three different spikelet positions of the male inflorescence during the study period on samples collected in peat soil areas at Site 1 and Site 2, Sarawak $(\mathrm{P}<0.05, \mathrm{P}=0.000-0.0047)$ (Table 2, Figures 7 and 8).

From samples collected in Site 1, only those collected in January 2016 showed no significant differences between the number of adult weevils lodged at different positions of spikelet $(P>0.05$,
$\mathrm{P}=0.129$ ) (Table 2). Whereas, in Site 2, samples collected in February, March, April, May, August, September, November 2015 and May 2016 showed no significant differences in terms of the number of adult weevils at the spikelets sampled from three different positions on the male inflorescences $(\mathrm{P}>0.05, \mathrm{P}=0.061-0.555)$ (Table 2).

In Site 1, the number of adults E. kamerunicus sampled from the top part of the inflorescence was significantly lesser compared to those collected from the bottom part $(\mathrm{P}<0.05, \mathrm{P}=0.000-0.047$, Site $1^{\text {Top }}=13.04$ weevils per spikelet; Site $1^{\text {Bottom }}$ $=26.83$ weevils per spikelet). However, there were no significant differences in the number of adult weevils collected from the middle and bottom parts of the inflorescence (Site $1^{\text {Middle }}=23.74$ weevils per spikelet, $\mathrm{P}>0.05$ ).

In Site 2, the adult weevils found lodged at the top spikelets at the inflorescences were significantly lesser than those at the bottom spikelets $(\mathrm{P}<0.05, \mathrm{P}=$ $0.000-0.041$, Site $2^{\text {Top }}=11.78$ weevils per spikelet; Site $2^{\text {Bottom }}=16.77$ weevils per spikelet).

Throughout the study period, the analysed data based on the monthly census conducted at the sites located on the mineral soils showed no significant differences between the number of adult weevils sampled from different portions of male inflorescences (Tables 2, 5 and 6, P>0.05, $\mathrm{P}=0.078$ 0.981 , Site $3^{\text {Top }}=28.51$ weevils per spikelet,Site $3^{\text {Middle }}=32.43$ weevils per spikelet, Site $3^{\text {Bottom }}$ $=33.60$ weevils per spikelet, Site $4^{\text {Top }}=26.67$ weevils per spikelet, Site $4^{\text {Middle }}=26.33$ weevils per spikelet, Site $4^{\text {Bottom }}=27.22$ weevils per spikelet). The graph illustrating this is shown in Figure 9 (Site 3) and Figure 10 (Site 4).

TABLE 1. MEAN ADULT Elaeidobius kamerunicus POPULATION DENSITY IN OIL PALM MALE INFLORESCENCES FROM DIFFERENT SOIL TYPES

\begin{tabular}{|c|c|c|c|c|c|c|}
\hline \multirow{2}{*}{ Sampling month } & \multicolumn{4}{|c|}{ Mean population density of weevils/ spikelet } & \multirow{2}{*}{ F value } & \multirow{2}{*}{ P value } \\
\hline & Peat & $\pm \mathrm{SE}$ & Mineral & $\pm \mathrm{SE}$ & & \\
\hline Jan 15 & $13.8222 b$ & 0.74 & $24.4537 a$ & 1.58 & 47.16 & $0.000^{*}$ \\
\hline Feb 15 & $8.9333 b$ & 0.48 & $28.9524 a$ & 1.66 & 178.36 & $0.000^{*}$ \\
\hline Mar 15 & $15.2278 b$ & 0.78 & $29.8056 a$ & 2.17 & 62.73 & $0.000^{*}$ \\
\hline Apr 15 & $21.0222 b$ & 1.53 & $34.3889 a$ & 2.27 & 25.69 & $0.000^{*}$ \\
\hline May 15 & $22.5778 b$ & 1.57 & $27.1905 a$ & 2.39 & 2.36 & 0.126 \\
\hline Jun 15 & $16.5772 b$ & 1.02 & $26.6270 a$ & 2.26 & 20.07 & $0.000^{*}$ \\
\hline Jul 15 & $30.55 a$ & 1.98 & $30.5139 a$ & 1.83 & 0.00 & 0.991 \\
\hline Aug 15 & $19.3889 a$ & 1.35 & $20.0238 a$ & 1.42 & 0.10 & 0.751 \\
\hline Sep 15 & $34.0778 \mathrm{a}$ & 2.49 & $31.0694 \mathrm{a}$ & 2.76 & 0.49 & 0.485 \\
\hline Oct 15 & $18.5500 a$ & 1.05 & $16.5556 a$ & 1.19 & 1.55 & 0.214 \\
\hline Nov 15 & $19.1722 b$ & 1.03 & $31.5694 a$ & 2.25 & 32.79 & $0.000^{*}$ \\
\hline Dec 15 & $16.1556 b$ & 1.45 & $34.7857 a$ & 1.98 & 60.14 & $0.000^{*}$ \\
\hline Jan 16 & $13.7278 b$ & 0.59 & $41.5000 \mathrm{a}$ & 4.50 & 135.35 & $0.000^{*}$ \\
\hline Feb 16 & $13.8056 b$ & 1.04 & $40.0556 a$ & 4.18 & 77.42 & $0.000^{*}$ \\
\hline Mar 16 & $12.7889 b$ & 0.6 & $31.2500 \mathrm{a}$ & 3.54 & 79.71 & $0.000^{*}$ \\
\hline Apr 16 & $18.6556 b$ & 1.05 & $39.5833 a$ & 4.26 & 47.91 & $0.000^{*}$ \\
\hline May 16 & $16.3278 b$ & 1.03 & $34.8611 \mathrm{a}$ & 3.90 & 41.45 & $0.000^{*}$ \\
\hline Jun 16 & $15.6889 \mathrm{~b}$ & 0.99 & $34.6389 a$ & 4.35 & 41.38 & $0.000^{*}$ \\
\hline
\end{tabular}

Note: Means that do not share a letter are significantly different. $\mathrm{SE}$ - standard error. ${ }^{*} \mathrm{P}<0.05$. 


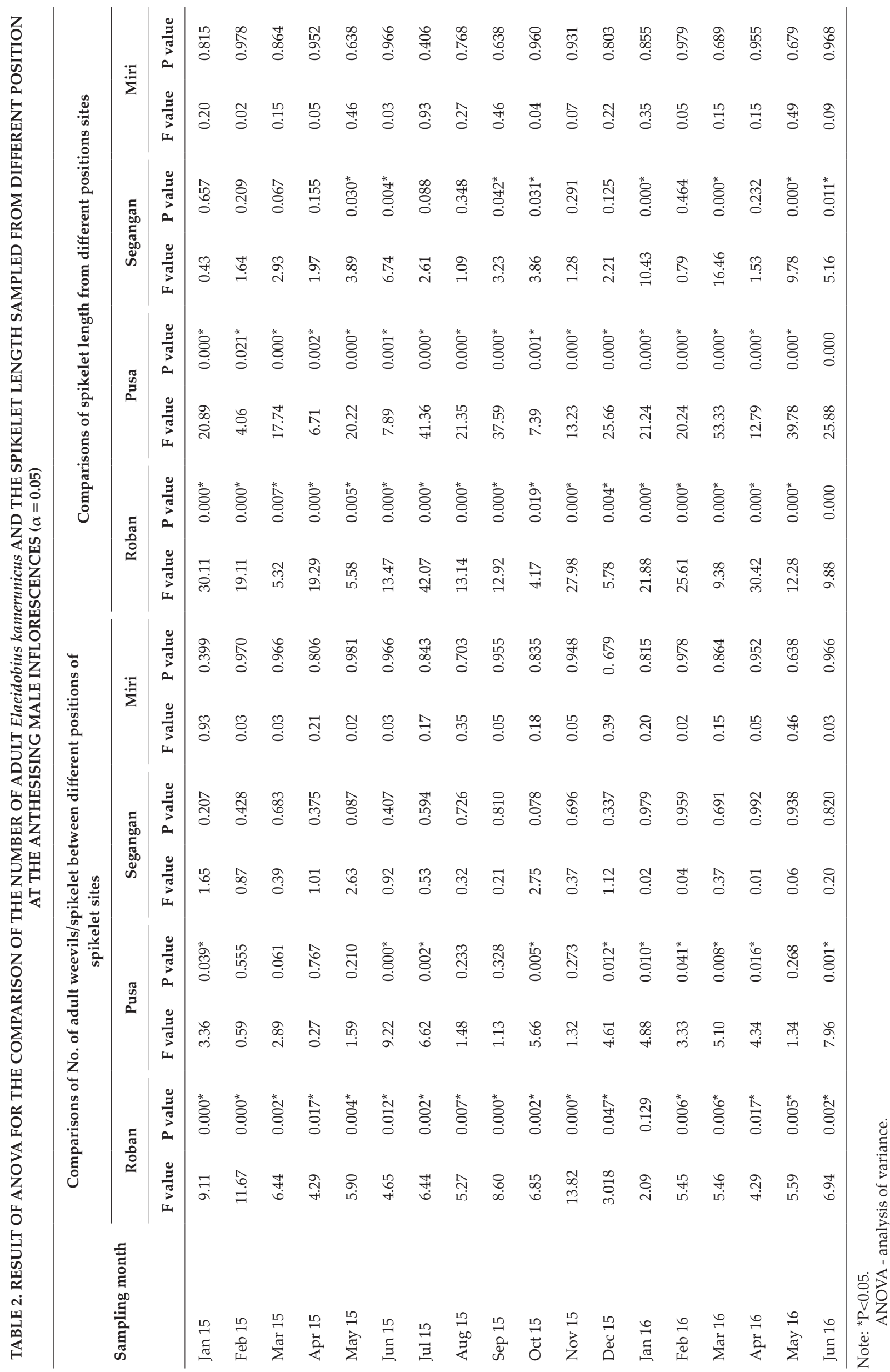




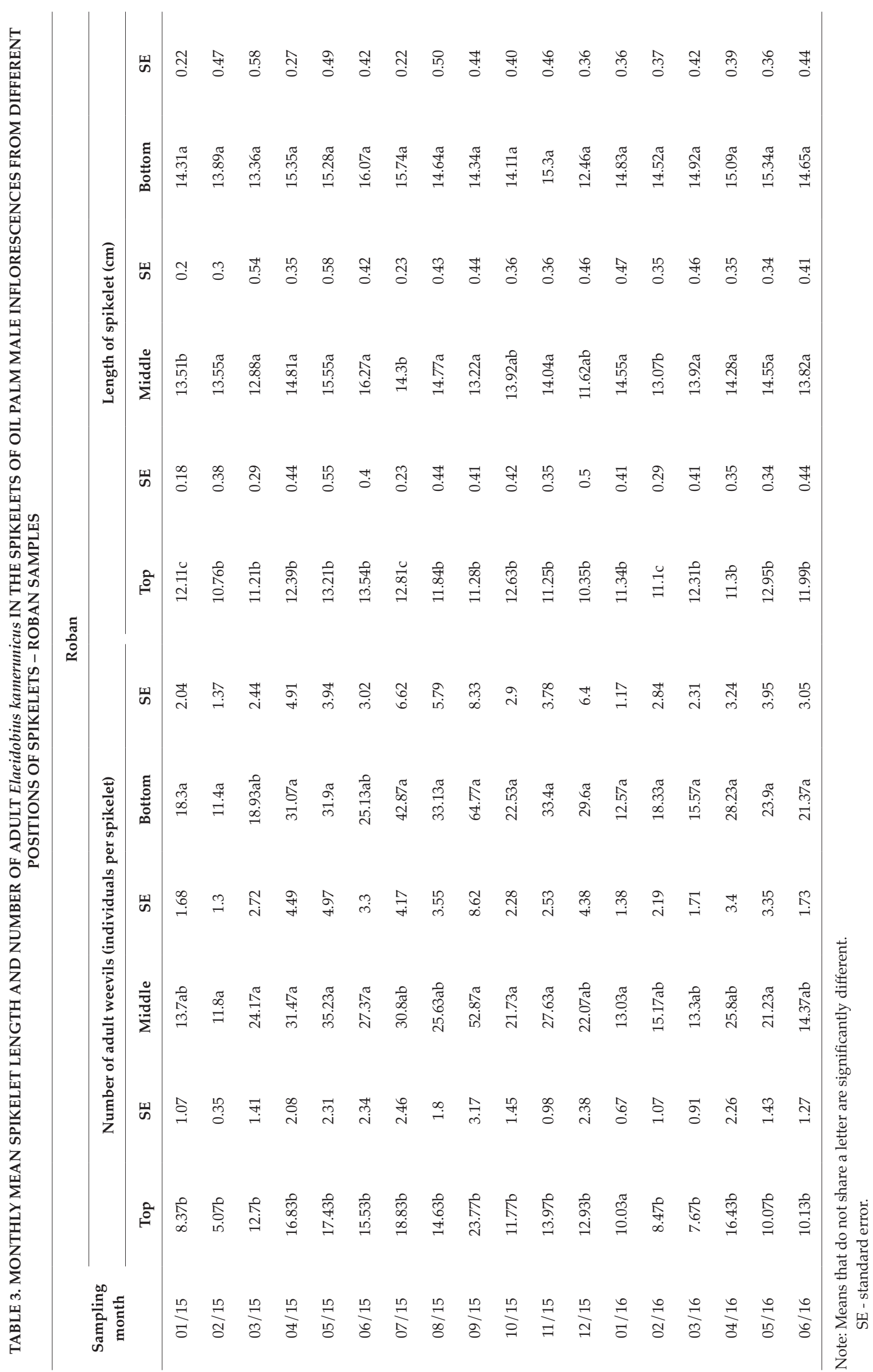




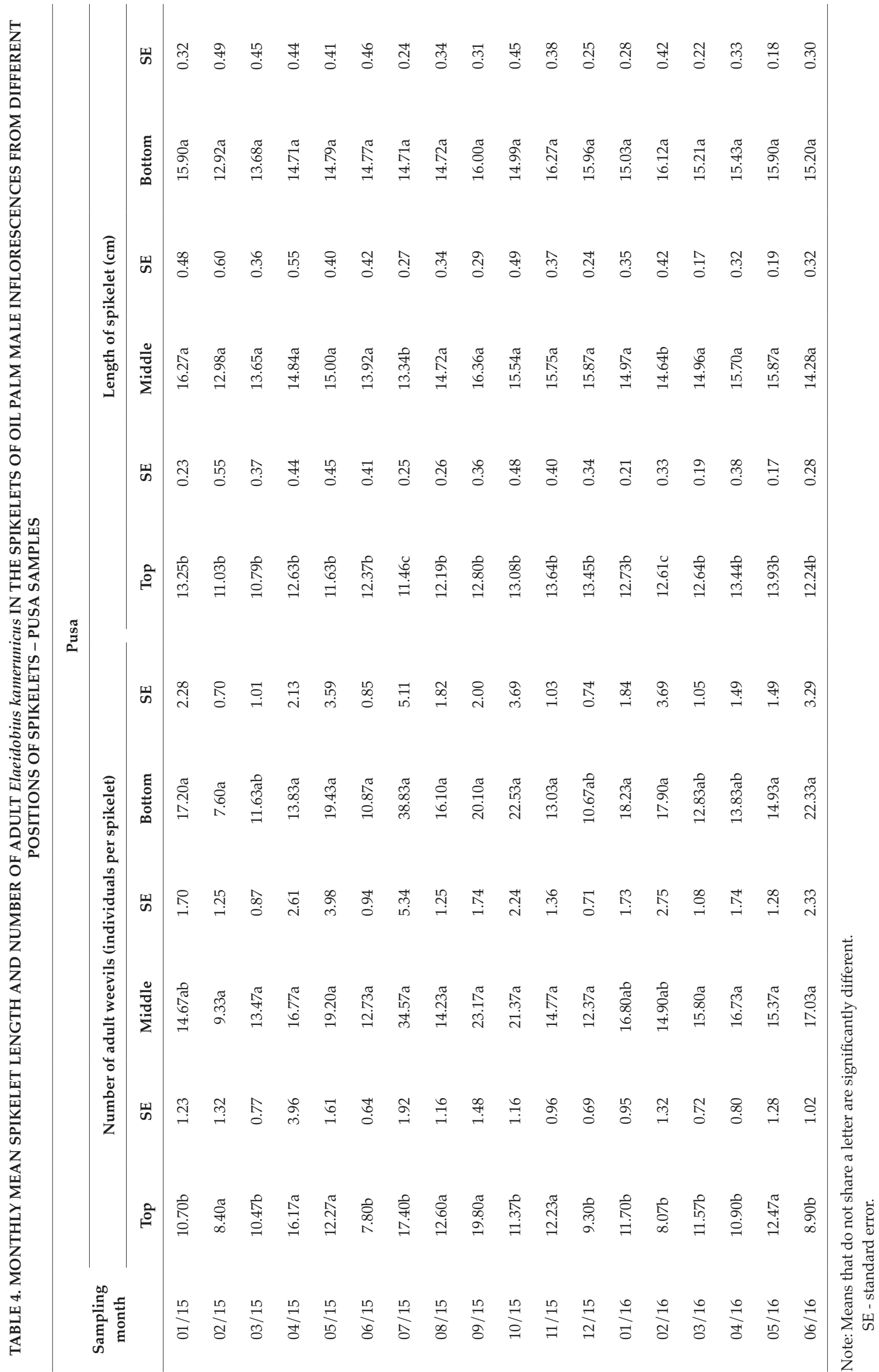




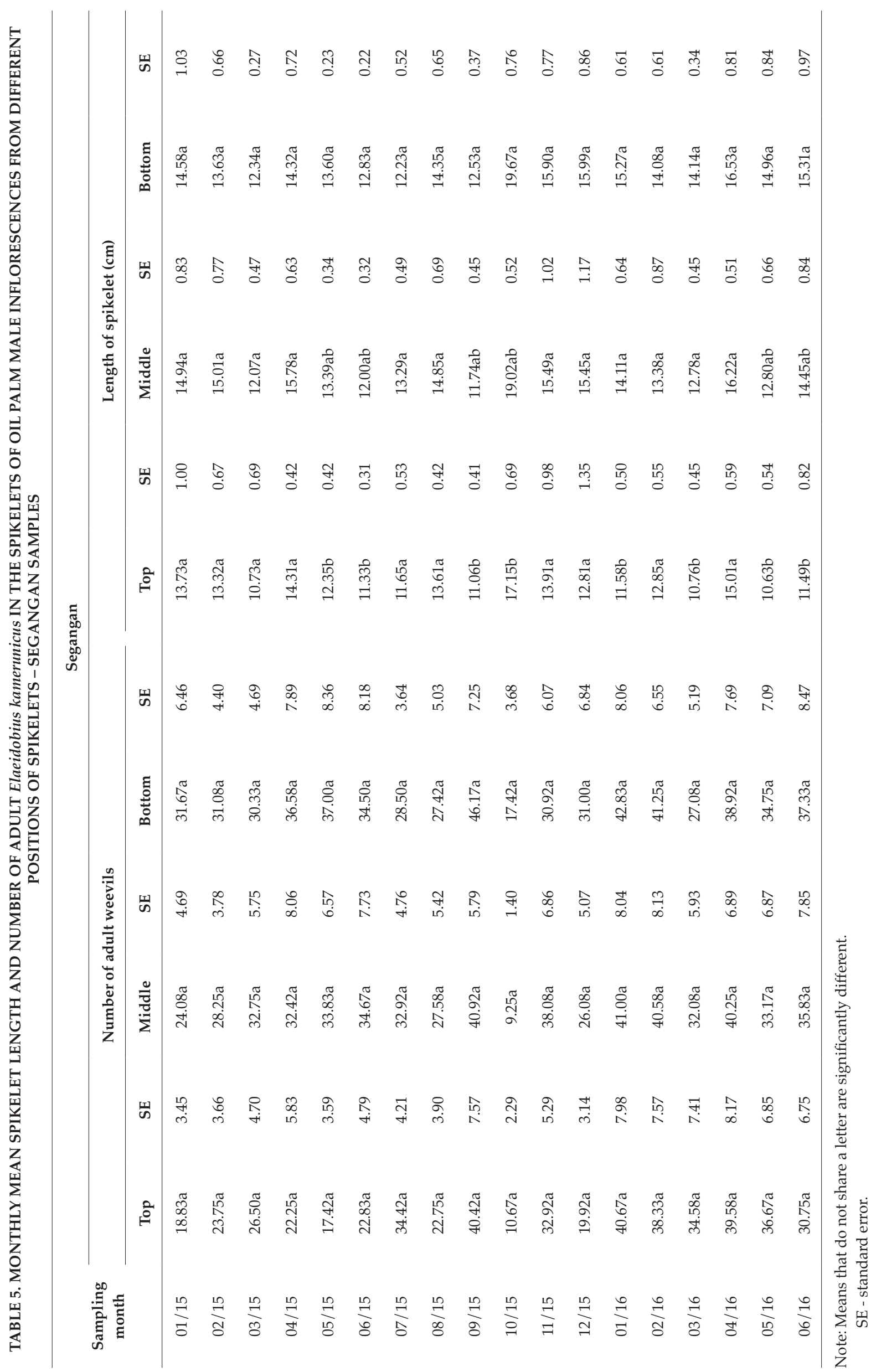




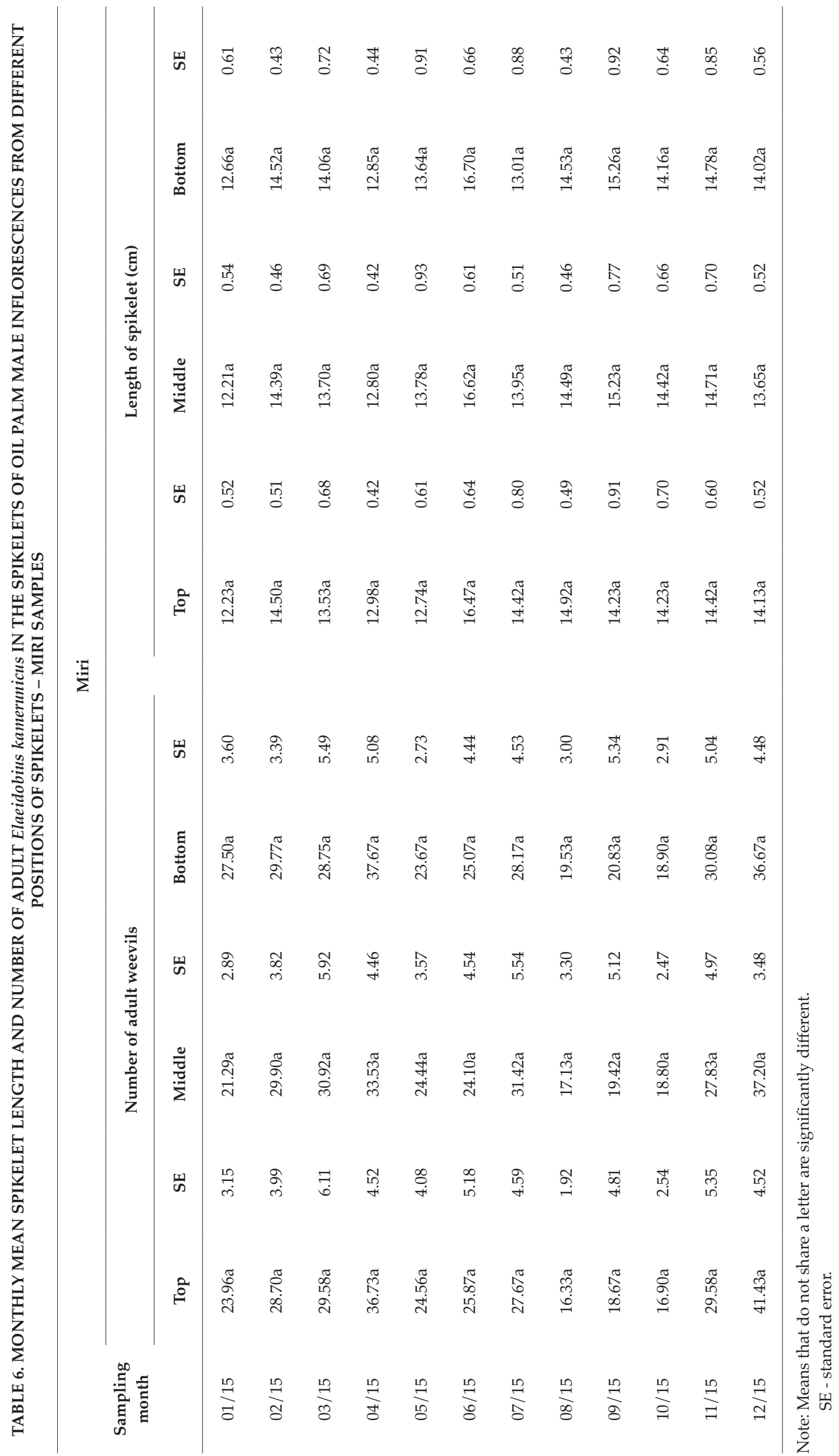


Length of spikelets according to portion of male inflorescences Site 1, Roban region, Sarawak, Malaysia
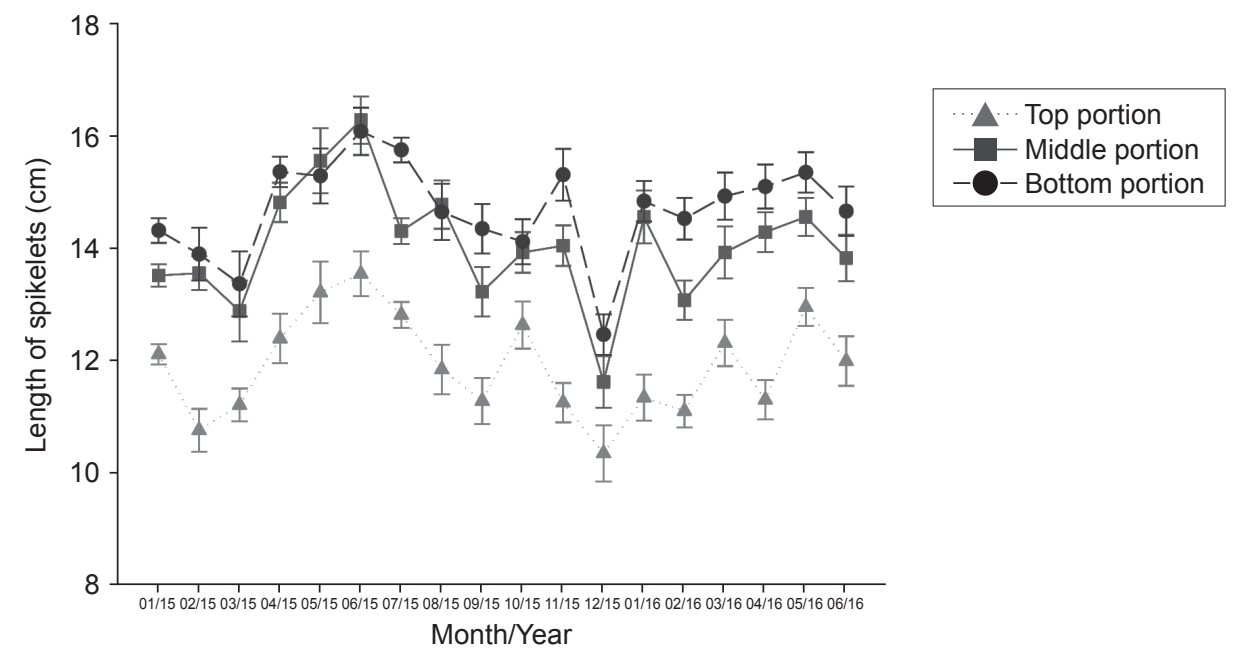

Figure 3. The length of spikelets (cm) in fully anthesising male inflorescence vs. the position of spikelets at Site 1, Roban, Sarawak, Malaysia.

Length of spikelets according to portion of male inflorescences Site 2, Pusa region, Sarawak, Malaysia
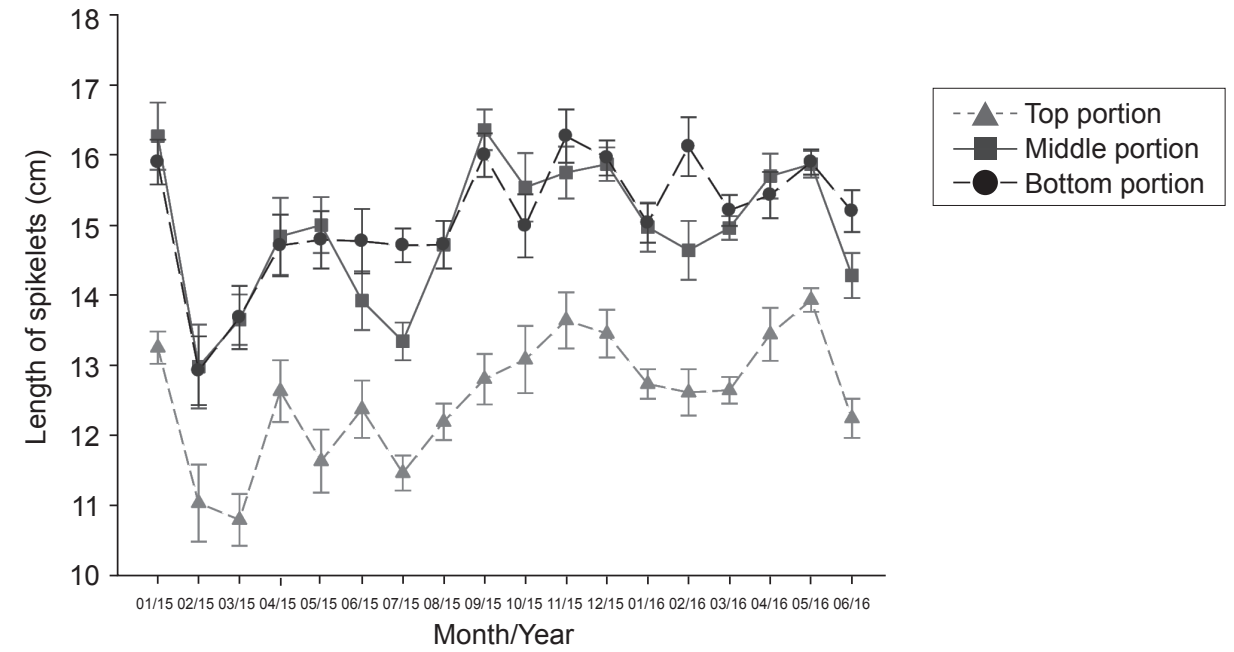

Month/Year

Figure 4. The length of spikelets (cm) in fully anthesising male inflorescence vs. the position of spikelets at Site 2, Pusa, Sarawak, Malaysia.

Length of spikelets according to portion of male inflorescences Site 3, Segangan, Sabah, Malaysia

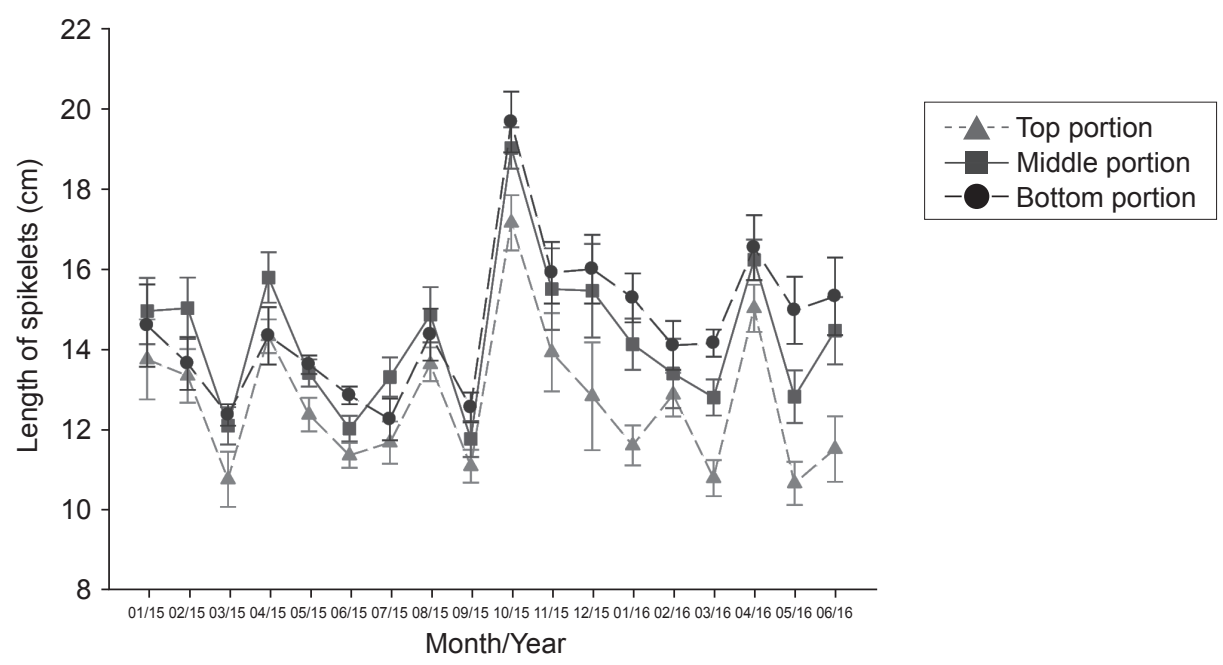

Figure 5. The length of spikelets (cm) in fully anthesising male inflorescence vs. the position of spikelets at Site 3, Segangan, Sabah, Malaysia. 
Length of spikelets according to portion of male inflorescences Site 4, Miri, Sarawak, Malaysia

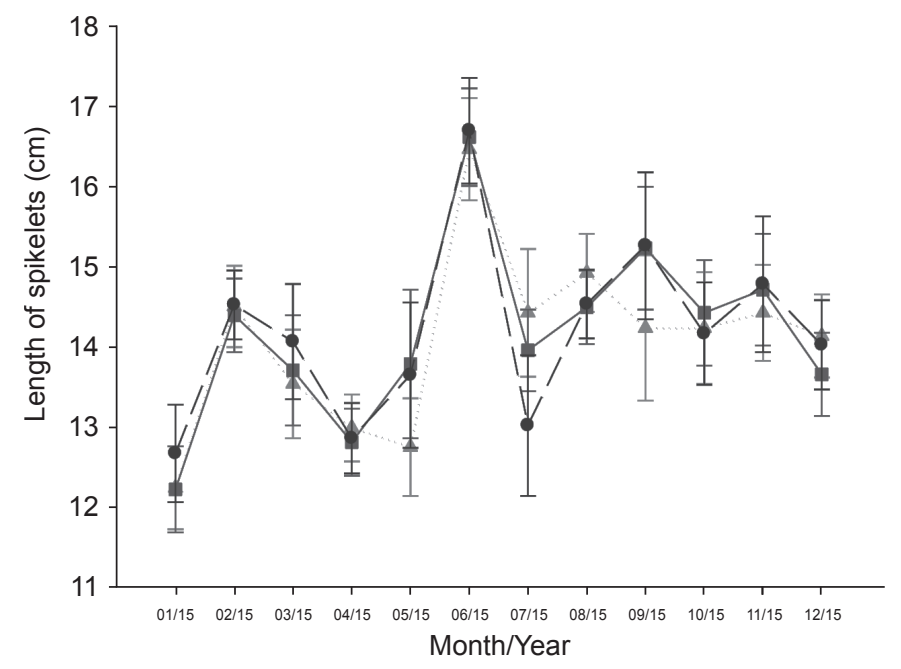

Figure 6. The length of spikelets (cm) in fully anthesising male inflorescence vs. the position of spikelets at Site 4, Miri, Sarawak, Malaysia.

No. of adult weevils according to portion of male inflorescences Site 1, Roban region, Sarawak, Malaysia

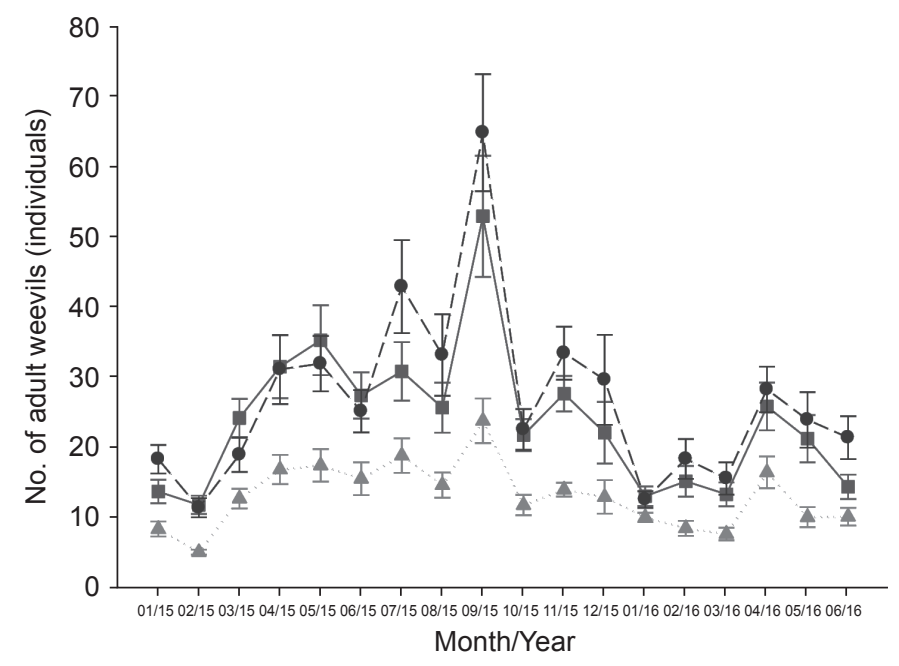

Figure 7. The number of adult Elaeidobius kamerunicus in fully anthesising male inflorescence vs. the position of spikelets at Site 1, Roban, Sarawak, Malaysia.

No. of adult weevils according to portion of male inflorescences Site 2, Pusa region, Sarawak, Malaysia

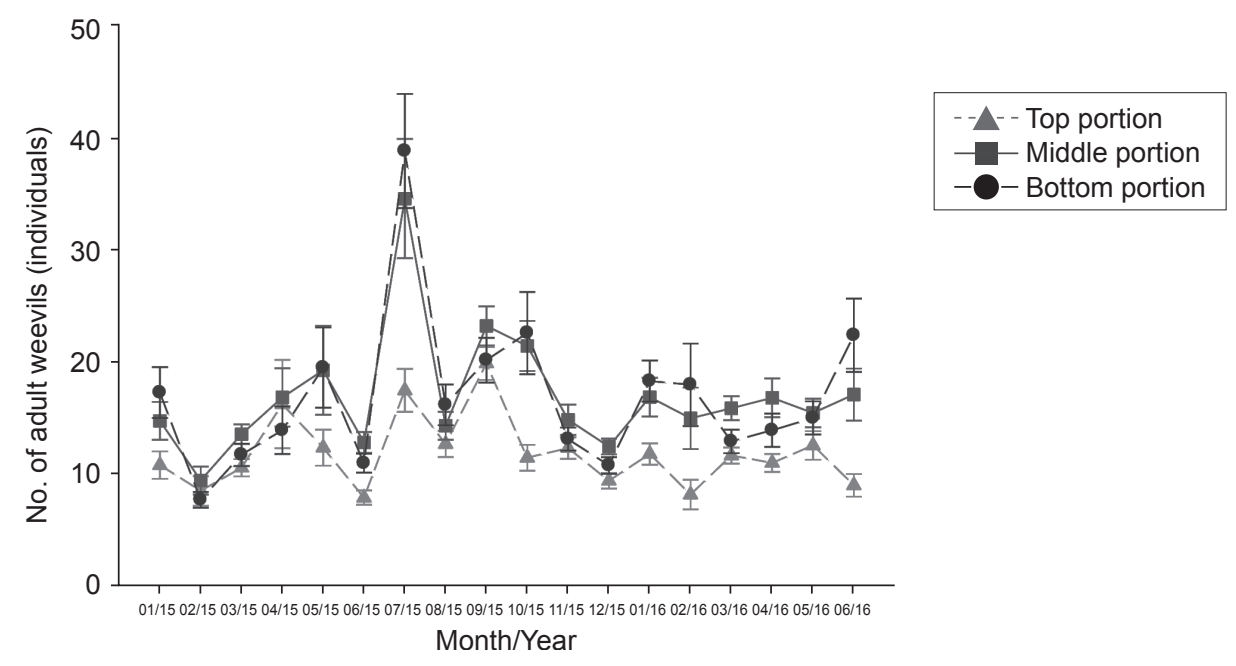

Figure 8. The number of adult Elaeidobius kamerunicus in fully anthesising male inflorescence vs. the position of spikelets at Site 2, Pusa, Sarawak, Malaysia. 
No. of adult weevils according to portion of male inflorescences Site 3, Segangan, Sabah, Malaysia

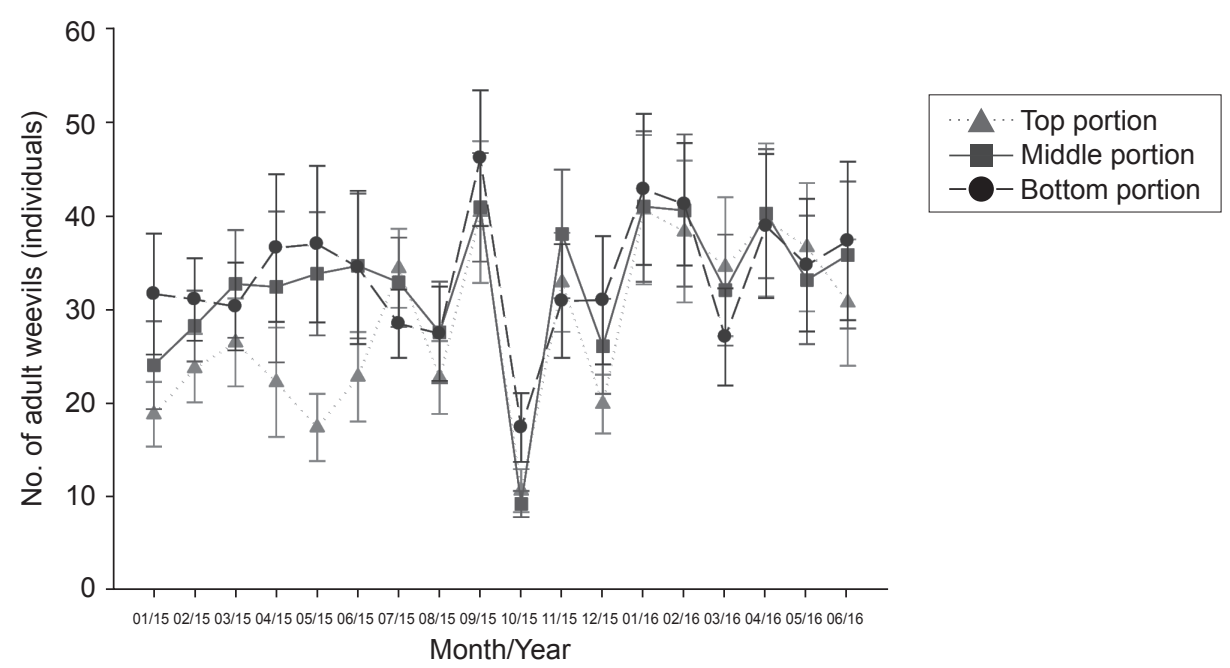

Figure 9. The number of adult Elaeidobius kamerunicus in fully anthesising male inflorescence vs. the position of spikelets at Site 3, Segangan, Sabah, Malaysia.

No. of adult weevils according to portion of male inflorescences Site 4, Miri, Sarawak, Malaysia
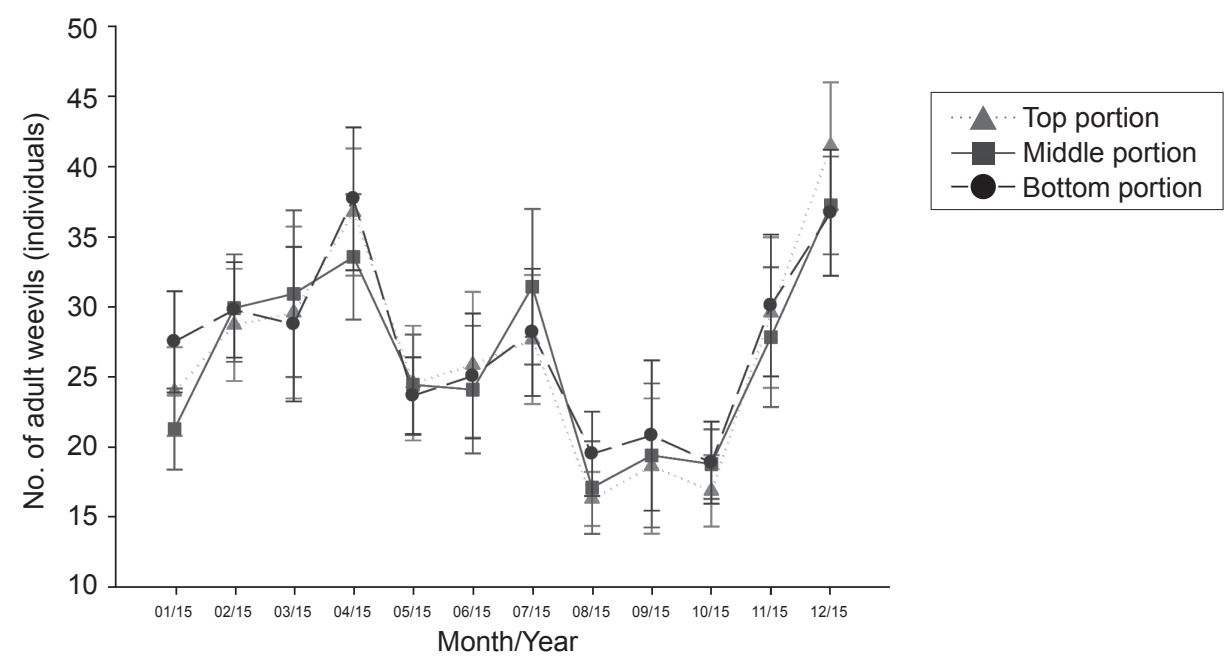

Figure 10. The number of adult Elaeidobius kamerunicus in fully anthesising male inflorescence vs. the position of spikelets at Site 4, Miri, Sarawak, Malaysia.

\section{Correlation between the Number of Adult Weevils and the Spikelet Length}

Weak positive correlations were found between the number of adults E. kamerunicus and the length of fully anthesising spikelets from the male inflorescences at Site 1, Sarawak (Table 7). The correlation coefficient at the site was at $r=0.154$ (top), $r=0.181$ (middle) and $r=0.155$ (bottom). Similarly, at Site 2, Sarawak, a positive correlation was found between the number of adults E. kamerunicus and the length of fully anthesising spikelets from the bottom part of the inflorescence. However, at $\mathrm{r}=0.161$, it was considered as weak and unreliable. Additionally, a weak positive correlation was also found for samples from the top part $(r=0.021)$ and the bottom part $(r=0.054)$ of the inflorescence (Table 7 ).

There were no significant correlations found between the number of adults E. kamerunicus and the lengths of fully anthesising spikelets from the top $(r=-0.090)$, middle $(r=-0.076)$, and bottom portion $(r=-0.059)$ of male inflorescences at Site 3, Sabah (Table 7). Similarly, there were also no correlations found between the number of adult weevils and the length of male inflorescences spikelet at Site 3, Sarawak (Table 7, $\mathrm{r}=0.041-0.072$ ). 
TABLE 7. CORRELATION COEFFICIENTS BETWEEN THE NUMBER OF ADULT Elaeidobius kamerunicus AND THE LENGTH OF SPIKELET IN FULLY ANTHESISING MALE INFLORESCENCES IN FOUR LOCALITIES IN SABAH AND SARAWAK, MALAYSIA

\begin{tabular}{|c|c|c|c|c|c|c|}
\hline Experimental site & Spikelet position & $\begin{array}{l}\text { Mean numbers } \\
\text { of adult weevil }\end{array}$ & SD & $\begin{array}{l}\text { Mean length of } \\
\text { spikelet }(\mathrm{cm})\end{array}$ & $\mathrm{SD}$ & $\begin{array}{l}\text { Correlation } \\
\text { coefficients }\end{array}$ \\
\hline \multirow[t]{3}{*}{ Site 1, Roban, Sarawak } & Top & 13.04 & 10.69 & 11.91 & 2.27 & $0.154^{* *}$ \\
\hline & Middle & 23.74 & 21.97 & 14.04 & 2.40 & $0.181^{* *}$ \\
\hline & Bottom & 26.83 & 25.83 & 14.68 & 2.36 & $0.155^{* *}$ \\
\hline \multirow[t]{3}{*}{ Site 2, Pusa, Sarawak } & Top & 11.70 & 8.43 & 12.55 & 2.09 & 0.021 n.s. \\
\hline & Middle & 16.92 & 13.32 & 14.93 & 2.28 & 0.054 n.s. \\
\hline & Bottom & 16.71 & 14.75 & 15.13 & 2.11 & $0.161^{* *}$ \\
\hline \multirow[t]{3}{*}{ Site 3, Segangan, Sabah } & Top & 28.51 & 20.94 & 12.68 & 2.83 & -0.090 n.s. \\
\hline & Middle & 32.43 & 22.33 & 14.26 & 2.89 & -0.076 n.s. \\
\hline & Bottom & 33.60 & 22.93 & 14.57 & 2.83 & -0.059 n.s. \\
\hline \multirow[t]{3}{*}{ Site 4, Miri, Sarawak } & Top & 26.98 & 21.46 & 14.19 & 3.06 & 0.041 n.s. \\
\hline & Middle & 26.31 & 20.17 & 14.17 & 2.97 & 0.045 n.s. \\
\hline & Bottom & 27.57 & 21.00 & 14.23 & 3.09 & 0.072 n.s. \\
\hline
\end{tabular}

Note: ${ }^{* *}$ Correlation is significant at $1 \%$ level.

n.s. - not significant

SD - standard deviation.

\section{DISCUSSION}

Since its introduction into Malaysia in the early 1980s, the early phase of the pollinating weevil population study was conducted subsequently to determine the species establishment in the country. The study conducted by Basri et al. (1987) confirmed the establishment of the weevil population. In the study, it was reported that the stable population levels in Sabah and Sarawak were at 31.5 weevils per spikelet. Afterward, except for a study by Cik Mohd Rizuan et al. (2013), no recent study to monitor the population of the pollinating weevil in East Malaysia was conducted. Compared to the findings by Basri et al. (1987), the results from this study revealed that the average weevil population at Site 1, Site 2, and Site 4, which are located in Sarawak, is lower. Only the average weevil population at Site 3 (Sabah) remains at 31.51 weevils per spikelet.

Throughout the period of this study, the weevil population density per spikelet fluctuated, from as high as more than 35 weevils per spikelet to less than 10 weevils per spikelet. Apparently, this trend was also reported in previous studies (Nurul Fatihah et al., 2018; Lubis et al., 2017; Syarifah Nadiah and Idris, 2016; Cik Mohd Rizuan et al., 2013). As highlighted by Khaliq et al. (2014), the insect population dynamics can be influenced by both abiotic and biotic factors. In E. kamerunicus case, especially in South-east Asia, the fluctuation in the population can be due to varieties of factors, including high rainfall (Prasetyo et al., 2010), excessive and improper insecticide usage especially on male inflorescences (Ming and Bong, 2017; Najib et al., 2012; Purba et al., 2012; Hutauruk et al., 1985), predation by rats, ants, spiders, birds, mites and nematodes (Muhammad Luqman et al., 2017; Bettycopa et al., 2015; Puan et al., 2011; Krantz and Poinar, 2004; Aisagbonhi et al., 2004; Poinar et al., 2002; Sipayung et al., 1987; Syed, 1979) and reduction in the number of male inflorescences arising from the planting of high yielding materials, which focus on the production of the greater amount of female inflorescences (Prasetyo et al., 2012; Purba et al., 2009). Some of the factors arose due to the management practices itself and are avoidable. The extreme and sustained decline in the pollinating weevil population may have deleterious effects on the oil palm fruit formation. However, in this study, the effects of the temporary reduction of E. kamerunicus populations on the pollination efficiency were not studied, and perhaps can be considered for future studies.

Compared to the study locations on the peat soil areas, higher weevil population density per spikelet was observed in sites located on mineral soil areas. Similar results were also reported by Lubis et al. (2017). As the age profile and the planting materials of the palms in all study locations were more or less the same, the differences in terms of the weevil population could be attributed to the different types of soil that the oil palms were planted on.

Different soil types have significant influences on oil palm yield (Veloo et al., 2015). They reported that the different peat characteristic (i.e. peat maturity and stage of composition) has the most significant effect on oil palm yield. Generally, oil palm planted on sapric soils has a higher yield compared to hemic soils. Mineral soils (i.e. sandy spodosol) also performed better than hemic soils. This was possible because oil palm roots are in 
contact with highly decomposed sapric materials, which is a better rooting and growth medium, compared to semi-decomposed hemic materials. In addition, hemic peat with a higher level of porosity may not have good nutrient retention properties, especially in areas with high rainfall. In a review by Woittiez et al. (2017), biochemically constrained soils such as peat soils were identified as one of the oil palm yield-limiting factors. This perhaps, explains the difference in oil palm inflorescence development between the sites located in peat soils and mineral soils.

In addition to climatic factors, Prasetyo et al. (2010) reported that the lower pollinating weevil population in peat soil areas was also due to a lack of anthesising male inflorescences, which is predominant in young mature areas. Montes et al. (2018) also concluded that the number of male inflorescences directly affecting the pollinator populations. The quantification of male inflorescence density was not conducted in this current study but it was found that the formation of male inflorescence, especially in terms of spikelet development in peat soil, was less uniform compared to those in mineral soil areas. The length of spikelets sampled from sites on mineral soils was similar throughout all different positions of the spikelets on the male inflorescences. However, in samples from peat soil areas, in most of the time, the top spikelets were significantly shorter than the bottom spikelets. To a certain extent, this has also influenced the number of weevils lodged at each spikelet. On peat soil, the number of adult weevils per spikelet from the top portion (which has the shortest length) of the inflorescences, was significantly less than those at the bottom portion (longest spikelets). This finding suggests that more weevils can be found on longer spikelets, although, in this study, no strong positive correlation was found between the length of spikelets and the number of weevils. However, in contrast, a study by Ponnamma et al. (2006) found a strong positive correlation between the number of weevils that emerged under laboratory conditions and the length of spikelets $(\mathrm{r}=0.4315)$. Ponnamma et al. (2006) suggested that longer spikelets provide more incentives (e.g. food sources and breeding sites) to the pollinating weevils compared to the shorter ones, and thus, more attractive. At Site 3 and Site 4, where the length of the spikelets was more uniform, no significant differences were found for both number of weevils for each part of the inflorescence. Similar length of spikelets in each portion of the male inflorescences meant that a similar amount of food sources and breeding sites were available to the weevils, regardless of the spikelets position. Different length of spikelets in male inflorescences on peat soil areas may also influence the population levels of the pollinator, and affected the pollination process.

\section{CONCLUSION}

The population of the oil palm pollinating weevils, E. kamerunicus at sites located on peat soil areas was lower than those on mineral soil areas. One of the factors that may contribute to this fact was the difference in the formation of male inflorescences spikelets, which serve to provide food sources and breeding sites for the weevil. It has been observed that the formation of the spikelets on peat areas tend to be less uniform than the spikelets formation on mineral soil areas. The spikelets from the upper part of the inflorescences were shorter compared to the spikelets from other parts of the inflorescences, which means a lower amount of food and breeding sources were available in these spikelets. This was further substantiated by a significantly lower number of weevils lodged at the spikelets sampled from the top portion of the male inflorescences. However, future studies can be done to study the effects of lower pollinator populations on the oil palm fruit formation. Additional studies on the cause of the differences in the inflorescence's formation and physical properties on peat soil and mineral soil areas are also recommended. It is also useful to know how the differences in the soil physical properties and nutrient availability influence the sexual determination of the inflorescences, causing the lack of male inflorescences availability in the field.

\section{ACKNOWLEDGEMENT}

The authors would like to extend their gratitude to the Director-General of MPOB for permission to publish this study. We would like to thank Zulkefli Masijan for his contributions to the study. Our gratitude also goes to the staff of the Entomology and Ecological Research Group (Entomology and Integrated Pest Management Unit) of MPOB Sessang, Sarawak, and MPOB Research Station Lahad Datu, Sabah, especially Mohd Faizal Sedie and Sindy Maurice Goulip, for their commitments to the project. Our appreciation also goes to the management of Tabung Haji Plantations, Hiew Kah Yung Estate and Sarawak Oil Palms Berhad for allowing us to conduct the trial at their respective estate and assisting us during the whole period of the study.

\section{REFERENCES}

Aisagbonhi, C I; Kamarudin, N; Okwuagwu, C O; Wahid, M B; Jackson, T A and Adaigbe, V (2004). Preliminary observations on a field population of the oil palm pollinating weevil Elaeidobius kamerunicus in Benin City, Nigeria. Int. J. Tropical Insect Science, 24(3): 255-259. 
Basri, M W; Zulkefli, M; Abdul Halim, H and Tayeb, D M (1987). The population census and the pollinating efficiency of the weevil, Elaeidobius kamerunicus in Malaysia - A status report, 19831986. Proc. of the 1987 International Oil Palm/Palm Oil Conferences. Progress and Prospect. PORIM, Bangi. p. 535-549.

Bettycopa, A; Andrew, A T; Khalid, H; Mohd Haniff, $\mathrm{H}$ and Kamarudin, N (2015). The diet of yellowvented bulbul (Pycnonotus goiavier) in oil palm agroecosystems. J. Oil Palm Res. Vol. 27(4): 417-424.

Chan, K Y; Oates, A; Swan, A D; Hayes, R C; Dear, B $S$ and Peoples, M B (2005). Agronomic consequences of tractor wheel compaction on a clay soil. Soil and Tillage Research, 89(1): 13-21.

Chiu, S B (1984). Some Aspects of the Ecology of Elaeidobius kamerunicus Faust, the Pollinating Weevil of Oil Palm, with Emphasis on Developing Sampling Techniques. Master thesis. Universiti Pertanian Malaysia, Selangor, Malaysia. http://psasir.upm.edu. my/10210/1/FP_1984_1_A.pdf

Chiu, S B; Khoo, K C and Hussein, M Y (1984). A method of estimating the natural population of the pollinating weevil, Elaeidobius kamerunicus Faust, of oil palm. Proc. of the First Regional Symposium on Biological Control. 4-6 September 1985, Universiti Pertanian Malaysia.

Cik Mohd Rizuan, Z A; Noor Hisham, $\mathrm{H}$ and Samsudin, A (2013). Role of pollinating weevil (Elaeidobius kamerunicus) seasonal effect and its relation to fruit set in oil palm area of FELDA. Proc. of the PIPOC 2013 International Palm Oil Congress. MPOB, Bangi. p. 19-21.

Corley, R H V (1976). Germination and seedling growth. Developments in Crop Science (Corley, R H V; Hardon, J J and Wood, B J E eds.). Vol. 1. Elsevier, Amsterdam, Netherlands. p. 37-54.

Corley, R H V and Tinker, P B (2015). The Oil Palm. $5^{\text {th }}$ Edition. John Wiley and Sons. West Sussex, United Kingdom. p. 37-42.

Hamza, M A and Anderson, W K (2005). Soil compaction in cropping systems. A review of the nature, causes and possible solutions. Soil and Tillage Research, 89(2): 121-145.

Haniff, M H and Roslan, M M N (2002). Fruit set and oil palm bunch components. J. Oil Palm Res. Vol. 14(2): 24-33.

Hussein, M Y; Lajis, N H and Ali, J H (1991). Biological and chemical factors associated with the successful introduction of Elaeidobius kamerunicus Faust, the oil palm pollinator in Malaysia. Acta Horticulturae, 288(1): 81-87.

Hutauruk, C H; Sudharto, P S; Siman-Gunsong, G and Sipayung, A (1985). Menjelang dua tahun serangga penyerbuk kelapa sawit Elaeidobius kamerunicus di Indonesia. Simposium Kelapa Sawit. 27-28 March 1985. Medan, Indonesia. p. 183-225.

Janick, J and Paull, R E (2008). The Encyclopedia of Fruit and Nuts. CABI Publishing, Oxfordshire, United Kingdom. 954 pp.

Kamaruddin, N; Moslim, R; Mohamad, S A and Sulaiman, M R (2018). Fruit set and weevil pollination issues in oil palm. The Planters: 565-581.

Khaliq, A; Javed, M; Sohail, M and Sagheer, M (2014). Environmental effects on insects and their population dynamic. J. Entomology and Zoology Studies, 2(2): 1-7.

Krantz, G W and Poinar, G O (2004). Mites, nematodes and the multimillion-dollar weevil. $J$. Natural History, 38(2): 135-141.

Lubis, F I; Sudarjat and Dono, D (2017). Populasi serangga penyerbuk kelapa sawit Elaeidobius kamerunicus Faust dan pengaruhnya terhadap nilai fruit set pada tanah berliat, berpasir dan gambut di Kalimantan Tengah, Indonesia. Jurnal Agrikultura, 28(1): 39-46.

Ming, S C and Bong, C F (2017). Effect of different insecticides on the survival of the oil palm pollinator, Elaeidobius kamerunicus (Coleoptera: Curculionidae). The Planter, 93(1100): 777-788.

Montes, B L G; Sanchez, L A; Prada, F; Daza, E S; Bustillo, A E and Romero, H M (2018). Relationships between inflorescences and pollinators and their effects on bunch components in Elaeis guineensis in Colombia. J. Entomological Science, 53(4): 554-568.

Muhamad Fahmi, M H; Ahmad Bukhary, A K; Norma, H and Idris, A B (2016). Analysis of volatile organic compound from Elaeis guineensis inflorescences planted on different soil types in Malaysia. The 2016 UKM FST Postgraduate Colloquium. AIP Conf. Proc., 1784(1). DOI: https: / / doi.org/10.1063/1.4966858.

Muhammad Luqman, H A; Dzulhelmi, M N; Idris, A B and Izfa Riza, H (2017). The potential natural predators of Elaeidobius kamerunicus Faust, 1878 (Coleoptera: Curculionidae) in Malaysia. Serangga, 22(2): 239-252. 
Najib, M A; Siti Ramlah, A A; Mohamed Mazmira, M M and Basri, M W (2012). Effect of Bt products, LEPCON-1, BAFOG-1 (S) and ECOBAC-1 (EC), against the oil palm pollinating weevil, Elaeidobius kamerunicus and beneficial insects associated with Cassia cobanensis. J. Oil Palm Res. Vol. 24: 1442-1447.

Nurul Fatihah, A L; Muhamad Fahmi, M H; Luqman, H A; Al-Talafha, H; Noor Nasuha, A A; Che Mohd Rizuan, Z A and Idris, A B (2018). Effect of oil palm planting materials, rainfall, number of male inflorescence and spikelet on the population abundance of oil palm pollinator, Elaeidobius kamerunicus Faust (Coleoptera: Curculionidae). Serangga, 23(1): 35-45.

Poinar, G O; Jackson, T A; Bell, N L and Wahid, M B (2002). Elaeolenchus parthenonema n. g., n. sp. (Nematoda: Sphaerularioidea: Anandranematidae n. fam.) parasitic in the palm-pollinating weevil Elaeidobius kamerunicus Faust, with a phylogenetic synopsis of the Sphaerularioidea Lubbock, 1861. Systematic Parasitology, 52(3): 219-225.

Ponnamma, K N; Asha, V and Sajeebkhan, A (2006). Progeny emergence in Elaeidobius kamerunicus. Planter, 82(962): 333-336.

Prasetyo, A E; Arif, M and Hidayat, T C (2012). Buah landak pada tanaman muda kelapa sawit. Warta Pusat Penelitian Kelapa Sawit, 17(1): 13-20.

Prasetyo, A E; Purba, W P and Susanto, A (2014). Elaeidobius kamerunicus: Application of hatch and carry technique for increasing oil palm fruit set. $J$. Oil Palm Res. Vol. 26: 195-202.

Prasetyo, A E; Supriyanto, E; Susanto, A and Purba, A R (2010). Population dynamics of Elaeidobius kamerunicus Faust, a case study on upland oil palm plantation. Proc. of the PIPOC 2011 International Oil Palm Congress. MPOB, Bangi. 668 pp.

Puan, C L; Goldizen, A W; Zakaria M; Hafidzi, M N and Baxter, G S (2011). Relationships among rat numbers, abundance of oil palm fruit and damage levels to fruit in an oil palm plantation. Integr. Zool., 6(2): 130-139.

Purba, A R; Supriyanto, E; Supena, N and Arif, M (2009). Peningkatan produktivitas kelapa sawit dengan menggunakan bahan tanaman unggul. Prosiding Pertemuan Teknis Kelapa Sawit (PTKS). 28-30 May 2009. Jakarta, Indonesia. p. 1-14.
Purba, R Y; Rozziansha, T A P and Pangaribuan, Y (2012). Strategies to improve effectiveness of pollination and productivity on early mature oil palm. Proc. of the Fourth IOPRI-MPOB International Seminar. Existing and Emerging of Oil Palm Pests and Diseases - Advance in Research and Management. 13-14 December 2012. Bandung, Indonesia. 409 pp.

Rahardjo, B T; Rizali, A; Utami, I P; Karindah S, Puspitarini, R D and Sahari, B (2018). Populasi Elaeidobius kamerunicus Faust (Coleoptera: Curculionidae) pada beberapa umur tanaman kelapa sawit. J. Entomologi Indonesia, 15(1): 31-39.

Sipayung, A; Duryadi, D and Lubis, A U (1987). Preferensi tikus terhadap jenis makanan dalam ekosistem perkebunan kelapa sawit. Laporan akhir kerjasama penelitian Pusat Penelitian Marihat- Biotrop SIMEO Bogor, Indonesia.

Syarifah Nadiah, S M D and Idris, A G (2016). Population density of oil palm pollinator weevil Elaeidobius kamerunicus based on seasonal effect and age of oil palm. The 2016 UKM FST Postgraduate Colloquium. AIP Conf. Proc. 1784(1). 5pp. DOI: https: / doi.org / 10.1063 / 1.4966889

Syed, R A (1979). Studies on oil palm pollination by insects. Bull. Entomol. Res., 69 (Dec 1979): 213-224.

Syed, R A (1980). Pollinating Insects of Oil Palm. Commonwealth Institute of Biological Control (CIBC) Report.

Syed, R A; Law, I H and Corvey, R H V (1982). Insect pollination of oil palm: Introduction, establishment and pollinating efficiency of Elaeidobius kamerunicus in Malaysia. The Planter, 58: 504-561.

Veloo, R; Ranst, E V and Selliah, P (2015). Peat characteristics and its impact on oil palm yield. NJAS-Wageningen J. Life Sciences, 72-73: 33-40.

Woittiez, L S; Wijk, M T V; Slingerland, M; Noordwijk, M V and Giller, K E (2017). Yield gaps in oil palm: A quantitative review of contributing factors. Euro. J. Agronomy, 83: 57-77.

Yahya, Z; Mohammed A T; Harun, M H and Shuib, A R (2012). Oil palm adaptation to compacted alluvial soil (Typic Endoaquepts) in Malaysia. J. Oil Palm Res. Vol. 24: 1533-1541. 